\title{
HISTORY AND FUTURE OF AUDITING IN RUSSIA
}

\author{
Iurii Guzov \\ St. Petersburg State University, Russia \\ Olga Strelnikova, \\ St. Petersburg State University, Russia \\ Viktoriia Iaremchuk \\ St. Petersburg State University, Russia
}

\begin{abstract}
This paper discusses the history and future of auditing in Russia. Through the application of this method, four stages in the recent history of auditing in Russia were identified: pre-history (the birth of the Russian auditing, the "wild" auditing); establishment of auditing in Russia; government regulation and licensing; self-regulation of audit activity. The concept of further development of audit activity in the Russian Federation is critically analyzed. Discussed the problems of the application of Technology Foresight in the auditing field.
\end{abstract}

Keywords: Foresight of auditing, historical stage, auditing standards, Concept of further development of audit activities in Russia

JEL code: M42, N80

\section{Introduction}

Auditing in its modern forms appeared in Russia in the second half of the 1980s, during the Perestroika period. It took almost 30 years, and today we have good reason to claim that 'auditing has become one of Russia's most successful business sectors' (Mennicken, 2010, p. 334). The recent history of Russian auditing also has its chroniclers and exegetes, both in Russia and abroad. The development of auditing in Russia and its first successes here were described in Enthoven and others (1998). Chronology of auditing development in the light of its legislative regulation and the evolution of its methodological framework were in sufficient detail presented in the monographs written by Sokolov, Terekhov (2004) and McGee, Preobragenskaya (2005). A. Samsonova-Taddei studied the evolution of a legislative framework for auditing in Russia as a local site of globalization (2009), and in particular, responses by local audit firms to the implementation of International Standards on Auditing (ISAs) in Russia (2013). P. Sucher and S. Bychkova (2001) have identified auditor independence rule requirements that have been implemented into the laws and codes of practice in Russia. A. Menniken (2008), taking a large post-Soviet Russian audit firm as an example, describes the circulation of international auditing standards as one of "connecting worlds" and translation. In Menniken (2010) the roles that images and ideas of market creation played in the re-articulation of relations between government, audit expertise and professional organizations in post-Soviet Russia are discussed. The case of one of the biggest Russian companies Gazprom and its auditor $\mathrm{PwC}$ is regarded as an example of globalization and multinational auditing in Alon and Dwyer (2012). Critically analyzed "the concept of further development of audit activity in the Russian Federation" I. Guzov (2016). Thus, some aspects of the recent history of auditing in Russia have attracted researchers' attention or have been investigated in a set of publications.

\section{History of Auditing in Russia}

Periodization. Logic addition of the considered chronological order of factors presents the history of audit development in Russia divided into the following time periods.

Period 1. 1987-1993, the prehistory (origination of Russian audit, i.e. 'wild' audit). Here we provide the marginal dates which outline the commencement of the independent audit history in Russia from creation of the first audit firm to adoption of the first legislative act on auditing. We have called 
this period primitive because at that time auditors worked outside the rules or standards using ISAs or Soviet state control rules for reference. Development of the law and auditing standards could be considered important and essential factors of the Russian audit profession's transition from this evolution stage to the next one.

Period 2. 1993-2001, formation of audit in Russia. This period runs from the introduction of the first regulatory act - Temporary Rules for Auditing Activity - to enactment of the first version of the Law on Auditing. The government licensing of auditing activity was introduced in the same period.

Period 3. 2001-2008, Government regulation and licensing. This period in the Russian audit history is limited by the enactment dates of two versions of the Law on Auditing. The whole period was characterized by brisk development of international cooperation resulting in the adoption of the first versions of the Russian Standards on Auditing (the tailored equivalent of ISAs) and the Code of Auditors' Ethics. The auditor qualification requirements were clearly outlined.

Period 4. 2009 until currently, developing an institute of self-regulatory audit. The last period in the Russian audit history is important because it marks a gradual shift of the regulatory center towards the professional community. Although the government still has the regulatory functions and the right to approve standards has passed from the Government to the Finance Ministry only, the professional self-regulating organizations have also received their share of powers. The government licensing of the auditing activity was abolished and the functions of certifying auditors and granting them rights to perform auditing activity have passed to the auditors' associations.

The content of the present-day stage of audit development in Russia is highlighted by the transition to international standard rules in auditing and to risk-oriented technologies in the circumstances of the audit market stagnation, the dramatic decrease in the number of qualified auditors, and the information lag and publication scarcity in terms of audit innovations coverage and of intensification of the system of audit quality control.

Audit history in Russia has started on September 8, 1987, of the Resolution of the USSR Council of Ministers "On Creating a Soviet Audit Organization". Pursuant to the provisions of this resolution, a corporation for providing audit services, Inaudit, was established under the auspices of the Chief Directorate of Monetary Control at the USSR Ministry of Finance. Regulatory control over auditing in Russia was at the initial stage of its development, and in 1991-1993, a draft law "On Audit Activity" was prepared. This was, in fact, a period of "wild" voluntary audit in the Russian Federation, which was based on a variety of different principles, starting from the rules of statutory audit to international auditing standards (used by the then Big Six, now the Big Four).

Presidential Decree № 2296 of December 12, 1993, introduced the first rules of audit activity in the form of "Provisional Rules of Audit Activity" as an independent business activity. These rules together with subsequent Resolutions adopted by the Government of the Russian Federation established a system of auditor certification and licensing of audit activity. Four kinds of auditor certificates and licenses were introduced: "general audit", "bank audit", "insurance audit" and "audit of commodity and stock exchanges", off-budgetary funds and investment institutions". Provisional rules of audit activity were the first general standards for auditing in Russia; they gave a definition of auditing and its types, asserted the principles of auditing as well as the rights and responsibilities of the auditor and the client, and also types of audit reports. A rapid growth in the number of auditors and audit firms followed, owing to the development of the mandatory auditing market. The first generation of auditing standards appeared, approved by the Commission on Auditing Activity under the President of the Russian Federation.

The first Federal Law "On Auditing” No. 119-FZ of July 13, 2001, consolidated the statutory framework for auditor certification and licensing of audit activity. New types of Federal Standards of Auditing Activity (FPSAD) were introduced, which greatly facilitated the rapid growth of the auditing market. 
Changes in the mechanism of audit regulation were heralded by the adoption of a new law "On Auditing” № 307-FZ of December 30, 2008. The institution of self-regulation of audit activity and a single auditor's qualification certificate were introduced in Russia. Six self-regulatory organizations (SROs) of auditors were established and began to work, of which five continue to operate today: Audit Chamber of Russia, Institute of Professional Auditors, Moscow Audit Chamber, Russian Collegium of Auditors, and Auditor Association Sodruzhestvo.

Changes in quantitative requirements for mandatory auditing, the need to retake an exam in order to obtain new auditor qualification certificates, and tightening of quality control over audit activity led to stagnation on the audit market and a sharp reduction in the number of auditors and audit firms.

Improvements in the standardization practice of audit activity. Prior to 1996 auditing in the Russian Federation had been carried based on company internal audit auditing standards. Russian auditing practices led to the formation and, thereafter, to the application of three generations of auditing standards nationwide. Currently the transition to ISAs has been pronounced. The first generation of Russian auditing standards, which all in all numbered 39, was elaborated in 1996-2001 and approved by the Russian Federation Presidential Commission on Auditing Activities. Contentwise, they comply with system-oriented auditing.

The second generation of auditing standards, also known as Federal Rules (Standards) of Auditing Activities (FPSAD), was formed between 2002 and 2008. Altogether, the Government adopted 34 rules which were formed on the basis of IASs analysis and, in essence, have acquired certain elements of risk-oriented auditing technologies.

Following that, in 2010-2011 the Russian Federation Ministry of Finance elaborated and adopted 11 Federal standards of auditing of the third generation. Content-wise, these standards closely approach those of ICA. The latest standards are supposed to be the final stage in preparation to the ICA transition planned for the year 2014.

Change in auditing techniques. Russian audit originated on the basis of revision technologies, which to a greater extent comply with the compliance audit, i.e. with the testing of the company accounting standards (Guzov, 2013), intuitive determination or ignoring the level of materiality, risks and sampling.

The complexity in defining the chronological order, in which a certain dominant audit technology was applied, can be explained by stratification of audit firms, their division into major, medium-size and small ones, also by the failure to obtain the objective data on the auditors' application of internal audit standard rules (Guzov, Savenkova, 2013; Guzov, 2014).

Practically from the very beginning major international audit companies (primarily the 'Big Four') started application of risk-oriented technologies in Russia in the beginning of the 1990s (Guzov, Strelnikova, 2015). More than that, these companies also train their employees using ACCA and CPA programs the successful completion of which was emphasized as a prerequisite for partnership in the said companies.

Realization of TASIS project Audit in Russia 1 in 2001 facilitated the mastery of risk-oriented technologies by major Russian audit companies. Work procedures and technology package of operational documentation applied in audit was laid open to public. The fact that major Russian audit companies joined international audit networks and won international audit tenders may serve indirect proof of their successful mastery of the technologies (Guzov, Strelnikova, 2015).

In the period between 1996 and 2008 Russian small and medium-size audit companies were mastering system-oriented audit techniques based on auditing standards. It seems that transition of small and medium-size audit companies to risk-oriented technologies is now at its beginning, since outside control reveals these companies' typical mistakes, i.e. a low level of audit planning, the failure to carry a review engagement before the auditor's opinion is formed, also the failure to provide a sampling description and risk assessment (Current problems..., 2013). 
Integration of Russian audit into the global system. Two stages can be distinguished in the process of Russian audit integration into the global system. The first one dates back to the years 2001 to 2006, and corresponds to the acquisition of technical aid from international organizations (TASIS project Audit in Russia 1 and 2 (translation of international audit standards in order to facilitate federal auditing rules).

Another stage was connected with the declared in 2017 adoption of international audit rules and the expected (in connection with that) engagement of Russian experts into their elaboration.

Situation on the Russian audit market. Judging from some estimates, there were around 800-900 audit firms with up to 5,000 practicing auditors in the time of 'wild' audit.

The first statistical survey of the Russian audit market was launched in 2006. Results of the expert analysis showed that somewhat 4,500-5,000 audit firms actually carried on business on the audit market in 2005. For purposes of the market analysis of audit services and relying on the credibility and accuracy of the available data, the number of audit firms in Russia in the year 2005 (i.e. within the time interval fixed through expertise) could be set at 4,700.

The development of the audit market of the period 2004-2008 is characterized by a quick growth of audit income, of the number of auditors and clients of audit firms. Yet, the level of modified audit opinion reports remained at approximately the same $40-50 \%$.

Major quantitative indices of the audit market development in Russia in the years 2005-2015 are shown in Table 1. The development of the audit market in the given period is characterized by stagnation of the audit firms' income. Implementation of self-regulation in audit profession and a new unified qualification certificate is followed by a dramatic decrease in the number of auditors, yet, with the number of audit firms remaining stable. Likewise, noticeable is the drastic decrease in the level of modified audit reports issuance.

Table 1. Russian audit market in the years 2005-2015

\begin{tabular}{|c|c|c|c|c|c|}
\hline Year & $\begin{array}{c}\text { Audit firms' } \\
\text { income (bln. } \\
\text { rubles) }\end{array}$ & $\begin{array}{c}\text { Number of } \\
\text { audit firms } \\
\text { (thous.) }\end{array}$ & $\begin{array}{c}\text { Number of } \\
\text { auditors } \\
\text { (thous.) }\end{array}$ & $\begin{array}{c}\text { Number of } \\
\text { clients (thous.) }\end{array}$ & $\begin{array}{c}\text { Level of modified } \\
\text { audit reports } \\
\text { issuance (\%) }\end{array}$ \\
\hline 2005 & 28.9 & 4.7 & 35.0 & 60.6 & 48.9 \\
\hline 2006 & 34.3 & 6.1 & 36.7 & 80.3 & 43.1 \\
\hline 2007 & 41.7 & 7.1 & 37.9 & 84.9 & 44.9 \\
\hline 2008 & 50.1 & 6.4 & 38.8 & 93.0 & 45.1 \\
\hline 2009 & 49.6 & 6.9 & 38.8 & 92.7 & 44.2 \\
\hline 2010 & 49.1 & 6.3 & 26.3 & 60.6 & 41.4 \\
\hline 2011 & 50.0 & 6.2 & $26.8(1.1)$ & 75.6 & 33.8 \\
\hline 2012 & 51.0 & 5.7 & $24.1(3.2)$ & 70.0 & 29.0 \\
\hline 2013 & 52.2 & 5.5 & $23.0(3.2)$ & 68.4 & 25.9 \\
\hline 2014 & 53.6 & 5.3 & $22.2(3.4)$ & 67.8 & 23.5 \\
\hline 2015 & 56.1 & 5.1 & $21.5(3.5)$ & 71.8 & 2.4 \\
\hline
\end{tabular}

Source: Main indicators of the market of audit services in the Russian Federation.

The trends for the stagnation of the audit firms' income and decrease in the number of auditors are likely to carry on in the nearest future.

Evolution of the academic coverage of audit theory and practice. In the 1990s much work was done under the editorship of Professor Y. V. Sokolov to have publications on audit translated from foreign languages. Thus, books by such authors as R. Adams (2005), Arens A. A. and Loebbecke J. K. (2001) saw light, as well as the translated standard textbook 'Montgomery's Auditing' (Defliese P., Jaenicke H., O'Reilly V. and Hirsch M., 1997). Publications released within the framework of TASIS project Audit in Russia 1 have made a vast contribution into the development of risk-oriented audit 
techniques. To summarize the project results a monograph by S. A. Remizov and N. A. Tabalina 'Auditing: Modern methodology: Audit of Financial Statements in Compliance with ISA and Federal Standards on Audit Activities (FPSAD)' (2003) was published. For the first time in history this book described Russian interpretation of risk-oriented audit programs.

There followed a series of profound research materials published in that period. Among them was the research work by V. Skobarya (1998) dedicated to audit documentation flow; by S. Bychkova and A. Gazaryan (1998), on planning, by Bychkova and L. N. Rasmathanova (2003), on risk appraisal and by Bychkova (1998), on audit evidence; by I. I. Eliseeva and A. A. Terekhov (1998), on sampling in audit. Modern technology audit is represented in the works I. Guzov $(2013,2015,2016)$.

Unfortunately, the textbooks on audit published in great numbers in the last twenty years as a general rule describe technologies of compliance audit and of the checks into regulatory bookkeeping and accounting. This evidently leads to the fact that employees working for small and medium-size audit firms fail to have a good handle in risk-oriented audit technologies and are very sensitive to whatever novelties are being introduced into audit standard rules.

Russian audit journals are generally focused on discussing issues in connection with the adaptation of audit standard rules and realization of audit programs. Independent academic studies in the sphere of audit are practically non-existent. No wonder that representatives from Russia rather seldom make reports at the European Congress of accountants. Such state of things, on the whole, indicates a serious information lag which a good number of Russian audit firms experience concerning modern riskoriented technologies of auditing. In 2013-2016 St. Petersburg State University was one educational organization which has a joint diploma with ACCA. And this is now becoming a general trend in Russian leading higher schools.

\section{Future of auditing in Russia}

The year 2016 saw the adoption of the "Concept of further development of audit activities in the Russian Federation", which determines the future development of Russian audit.

The Concept defines the goal, the main objectives and priorities for further development of audit in the Russian Federation. The Concept aims to provide:

1) assessment of the current state of audit as an institution and major problems of its development;

2) determination of a basic long-term target model for the organization, management and implementation of auditing;

3) fulfilling the potential of the institution of auditing as an important element of Russian financial system;

4) determining measures needed to achieve the goal of further development of audit activity, their sequence and timing.

According to the Concept, the main outcomes of audit development in Russia are:

1. sustainable functioning of the audit market that has a significant potential for further development;

2. formation of regulatory support of auditing;

3. creation of the institutions of the auditing profession and the audit market;

4. institutionalization of the auditing profession;

5. creation of a modern system of registration of audit firms and auditors;

6. creation of a modern system of professional certification for auditors;

7. establishment of a comprehensive system for exercising external quality control over audit firms and auditors, and exerting influence on those who violate the requirements and regulations;

8. creation of favorable conditions for information openness on the audit market; 
9. establishment of an independent system of public oversight of the auditing institution, separate from the auditing profession;

10. general compliance of Russian auditing with an internationally recognized model.

Audit market crisis, a transition to international auditing standards, a need to reorganize the system of self-regulation, enhancing quality control efficiency, structuring the auditing profession, increasing administrative and financial pressure on small and medium-sized audit firms, changes in legislation and opening the Russian audit market for foreign auditors - such is the list of the most relevant problems of Russian auditing.

The Concept needs serious revision and updating. Concepts involve strategic analysis, establishment of a goal-setting system and development of a mechanism for implementing the concept in the foreseeable future. Modern concepts are often designed using a foresight technology. Modern foresight ("vision of the future" in English) is an effective tool for shaping priorities and mobilizing a substantial number of participants to achieve the new quality of results in the field of science and technology, economy, state and society. Based on the results of foresight projects, road maps are created. Foresight methodology serves as a platform for dialogue between various policy actors, a tool for networking, as well as information basis for adaptive policies and strategies. It is emerging as an important tool for building a new society, the engine of transformation changes in society. The main actors are represented by the elements of the triangle of audit market interests: authority (regulator) - business (auditors) - report users (population and non-auditor businesses).

\section{These actors have the following predominant interests:}

Regulator: fiscal interests and monitoring of accounting discipline, maintaining legislative and regulatory balance on the audit market, protection of the Russian audit market.

Auditors: audit market expansion, maintaining normal competition on the audit market.

Report users: reducing market and accounting risks through the use of audit activities.

Another direction of formalizing foresight includes identifying major world trends in the development of accounting and auditing. These include:

- Accounting innovations: development of non-financial reporting forms and their combination with financial statements as the auditing subject matter. Emergence of integrated reporting and development of a methodology of integrated reporting audit.

- Development of computer-based accounting brings up the question of continuous customer audit (real-time auditing).

- Substantial progress of internal audit, leading to the creation of so-called "risk passports", risk heat maps, risk appetite, and matrices for control of one's own organization, seriously strengthens the possibility of conducting a risk-oriented audit. Risk is becoming the subject matter of accounting and auditing, along with traditional accounting elements.

- Development of new formats of audit opinion and engagements that guarantee confidence.

- Expansion of the types of audit engagements providing different levels of confidence.

- Combination of auditing practices and business rating system in order to reduce business risks.

Sections 2 and 3 of the Concept entitled "Major outcomes of the audit institution development" and

"Basic problems of auditing development" are traditional sections which are descriptive in nature. Section 3 presents a regulator's point of view on the situation. But auditors and report users may have a different view.

The wording of the main goal of "further development of audit activities in the Russian Federation", which is "forming and maintaining the confidence of business community and society in general to the results of audit services", can be considered satisfactory. To achieve this goal, the following basic objectives should be met:

1) improving the quality of auditing services; 
2) boosting the competitiveness of audit organizations and individual auditors;

3 ) promoting the auditing profession.

Meeting these objectives involves targeted implementation of a range of regulatory, organizational and other measures to:

1) improve the framework of the audit market;

2) improve the auditing regulatory system;

3) develop the auditing profession and audit market institutions;

4) improve the system of auditors' professional certification and continuing training;

5) develop systems for monitoring and oversight of auditing as well as penalties;

6) increase the level of involvement of the Russian auditing profession in international activities.

However, there is a certain logical inconsistency in the draft of the Concept. It identifies seven basic problems, while indicating only three objectives in achieving the goal and six directions of measures. Therefore, some part of the problems is not significant and not subject to impact. Moreover, the wording of the objectives and directions of measures is declarative in nature. Measures may logically conflict with the objectives.

In our opinion, the logic of the concept should be as follows:

- The main international trends of audit development (foresight);

- Strategic analysis of the development of Russian audit (problems and remoteness from international trends);

- Goal-setting section;

- Mechanisms for achieving the goals and objectives;

- "Road map" to achieve the stated goals.

In our opinion, the purpose of further development of audit activity in the Russian Federation should be active involvement and adaptation to the conditions of the global audit market since the key innovation will imply a transition to international auditing standards and the establishment of the audit market as part of the Eurasian Economic Union.

Without repeating what is contained in the draft, we suggest that the following must be added to the section about internal auditing objectives and measures:

1. Promotion of the unionization of small and medium-sized audit firms and creation of internal networks. It is necessary to encourage the creation or amalgamation into larger regional auditing companies which will be capable of withstanding the increasing competition on the audit market and fully complying with all the requirements of auditing standards. They should be made up of no less than 12-15 auditors, including 1-2 auditors with new qualification certificates and 1 quality controller. Such a union will favor partnership between the heads of smaller audit companies and improve systematic work on compliance with auditing standards. However, for this idea to be implemented in order to maintain regional businesses, there is a need for rather serious efforts from the heads of the operating companies.

2. Development of a new "white paper" of self-regulatory audit organizations, which would indicate new organizational approaches towards uniting individuals or legal entities for the purpose of self-regulation.

3. Formation of a system of interaction between auditing firms and rating agencies in order to reduce business risks and the cost of external financing for economic actors. Rating customers is widely spread in the banking business, serving as a basis for risk assessment and reserve calculations. External confirmation of this data reinforces its authenticity, reducing risks for financial institutions and interest rates for law-abiding customers.

4. Development of "road maps" for interaction between the regulator, auditors and report users in achieving the set goals. 
5. Discussion about the introduction of a "mandatory review" to broaden the scope of the audit market, develop an integrated system of control on the Russian market and expand a reliable ranking base.

A major test of the Russian auditing will start on 2017.01.01. The new quantitative requirements for self-regulatory organizations audit (2,000 members of legal entities or physical person members 10,000) seriously reflow Russian audit. The unpreparedness of the Auditors to the situation, administrative pressure will cause massive closure of smaller audit firms and audit of monopolizing the market.

\section{Bibliography}

Adams, R. (2005). Audit Framework. Translation from English Under the Edition of Y. V. Sokolov (Moscow: UNITI) [Адамс P. Основы аудита]. (in Russian)

Alon, A., Dwyer, P. D. (2012). Globalization and Multinational Auditing: The Case of Gazprom and PwC in Russia, Behavioural Research in Accounting, 24 (1), pp. 135-160.

Arens A. A., Loebbecke J. K. (2001). Auditing. An Integrated Approach. Translation from English. Under the Edition of Y. V. Sokolov (Moscow: Finance and Statistics) [Аренс Э. А., Лоббек Д. К. Аудит]. (in Russian)

Bychkova, S. M. (1998). Audit Evidence. Moscow: Finance and Statistics. [Бычкова C.M. Доказательства в аудите]. (in Russian)

Bychkova, S. M., Gazaryan, A. V. (2001). Audit Planning. Moscow: Finance and Statistics. [Бычкова C. М., Газарян А. В. Планирование в аудите]. (in Russian)

Bychkova, S. M., Rasmathanova, L. N. (2003). Audit Risks. Moscow: Finance and Statistics) [Бычкова С. М., Расматханова Л. Н. Риски в аудиторской деятельности]. (in Russian)

Defliese, P., Jaenicke, H., O’Reilly, V., Hirsch M. (1997). Montgomery's Auditing. Translation into Russian by S. M. Bychkova under the edition by Y. V. Sokolov. Moscow: Audit: UNITI. [Дефлиз Ф. Л., Дженик Г. Р., О’Рейли В. М., Хирш М. Б. Аудит Монтгомери]. (in Russian)

Enthoven,, A., Sokolov, Y., Bychkova, S., Kovalev, V., Semenova, M. (1998). Accounting, Auditing and Taxation in the Russian Federation. The University of Texas Press.

Eliseeva, I. I., Terekhov, A. A. (1998). Statistical methods in Auditing. Moscow: Finance and Statistics. [Елисеева И. И., Терехов А. А. Статистические методы в аудите]. (in Russian)

Guzov, I. (2013). Risk-oriented approach and the problems of formation of the system of internal control' Audit Journal, 1, pp. 62-71 [Гузов Ю. Риск-ориентированный подход и проблемы формирования системы внутреннего контроля аудиторских фирм]. (in Russian)

Guzov, I., Savenkova, N. (2013). Due diligence: the identification and assessment of risks associated with the acquisition of the investment object. Audit and financial analysis, no. 2, pp. 201-206 [Гузов И., Савенкова Н. Дью-Дилидженс: Выявление и оценка рисков, связанных с приобретением объектов инвестирования].

Guzov, I., Strelnikova, O. (2015). Planning Practice in a risk-focused audit. Audit Journal, 1, pp. 2941 [Гузов Ю., Стрельникова О. Практика планирования в риск ориентированном аудите].

Guzov, I. (2016). To the formation of the concept of further development of audit activity in the Russian Federation. Audit 6, pp. 10-14 [Гузов Ю., К вопросу формирования «Концепции дальнейшего развития аудиторской деятельности в Российской Федерации»]. (in Russian)

Guzov, I. (2016) History of auditing in Russia. Periodization and challenges of development. Audit financiar, XIV, NO. 6 (138), pp. 651-658. 
McGee, R., Preobragenskaya, G. (2005). Accounting and Financial System Reform in a Transition Economy: A Case Study of Russia. New York: Springer.

Mennicken, A. (2010). From Inspection to Auditing: Audit and Markets as Linked Ecologies. Accounting, Organizations and Society, 35 (3), pp. 334-359.

Samsonova-Taddei, A. (2013). Social Relations and the Differential Local Impact of Global Standards: The Case of International Standards on Auditing. Abacus, 49 (4), pp. 506-538.

Skobarya, V. V. (1998) Auditing: Methodology and Organization. Moscow: Business and Services. [Скобара В. В. Аудит: методология и организация]. (in Russian)

Sokolov, Y. V., Terekhov A. A. (2004). Essays on the Development of Auditing. Moscow: FBK Press. [Соколов Я. В., Терехов А. А. Очерки развития аудита]. (in Russian)

Sucher P., Bychkova S. (2001). Auditor independence in economies in transition: a study of Russia. European Accounting Review, 10 (4), pp. 817-841. 